\title{
Detection of Multiple Verticillium Species in Soil Using Density Flotation and Real-Time Polymerase Chain Reaction
}

J. Debode and K. Van Poucke, Plant Sciences Unit - Crop Protection, Institute for Agricultural and Fisheries Research (ILVO), Burg. van Gansberghelaan 96 bus 2, 9820 Merelbeke, Belgium; S. C. França, Laboratory of Phytopathology, Department of Crop Protection, Faculty of Bioscience Engineering, Ghent University, Coupure links 653, 9000 Ghent, Belgium; M. Maes, Plant Sciences Unit - Crop Protection, Institute for Agricultural and Fisheries Research (ILVO), Burg. van Gansberghelaan 96 bus 2, 9820 Merelbeke, Belgium; M. Höfte, Laboratory of Phytopathology, Department of Crop Protection, Faculty of Bioscience Engineering, Ghent University, Coupure links 653, 9000 Ghent, Belgium; and K. Heungens, Plant Sciences Unit - Crop Protection, Institute for Agricultural and Fisheries Research (ILVO), Burg. van Gansberghelaan 96 bus 2, 9820 Merelbeke, Belgium

\begin{abstract}
Debode, J., Van Poucke, K., França, S. C., Maes, M., Höfte, M., and Heungens, K. 2011. Detection of multiple Verticillium species in soil using density flotation and real-time polymerase chain reaction. Plant Dis. 95:1571-1580.

Wet sieving of soil samples, followed by plating on semi-selective medium and microscopic analysis, is the most commonly used technique to quantify microsclerotia-forming Verticillium species in soil. However, the method is restricted to small samples, does not allow easy differentiation between species, and takes several weeks to complete. This study describes an alternative method to test 100 -g soil samples for three Verticillium species (V. tricorpus, V. dahliae, and V. longisporum) using density flotation-based extraction of microsclerotia followed by new real-time polymerase chain reaction (PCR) assays.

DNA internal transcribed spacer for $V$. tricorpus and the $\beta$-tubulin gene for $V$. dahliae $+V$. longisporum and $V$. longisporum. Tests with artificially and naturally infested soils showed that the new method is reproducible and sensitive ( 0.1 to 0.5 microsclerotia/g soil), allows differentiation among the three species, and can be completed in one day. The results of the new method and the wet-sieving method were highly correlated for $V$. tricorpus $\left(R^{2}=0.78\right)$, but not for $V$. dahliae/V. longisporum, probably due to the loss of germinability of $V$. dahliae/V. longisporum microsclerotia during prolonged dry storage of the soil.
\end{abstract} Primers for these real-time PCR assays were designed to the ribosomal
Soils can contain multiple microsclerotia-forming Verticillium species, such as $V$. dahliae Kleb., V. longisporum (ex. V. dahliae var. longisporum Stark; comb. nov. Karapapa), and V. tricorpus I. Isaac $(15,22)$. $V$. dahliae infects a wide range of mainly noncruciferous hosts, including ornamentals, fruits, vegetables, and trees (22). V. longisporum almost exclusively infects crucifers, including cauliflower and oilseed rape. $V$. longisporum was described for the first time in 1997 by Karapapa et al. (21) based on distinctive morphological, molecular, and virulence characteristics compared to $V$. dahliae (e.g., V. longisporum has longer conidia, nearly double the DNA content, and mainly infects crucifers). It has been suggested that $V$. longisporum arose from a hybridization event between $V$. dahliae and V. albo-atrum, or V. dahliae and another (as yet unidentified) species $(5,6,21)$. During the last 10 years, taxonomic controversy has evolved as to whether $V$. longisporum should be a separate species from $V$. dahliae (22). Therefore, $V$. longisporum isolates were also often referred to as "long-spored", "near diploid", or "amphihaploid" $V$. dahliae isolates $(2,6,31)$. However, recent evidence indicates that $V$. longisporum is a distinct hybrid species (19). V. tricorpus is a saprophyte or weak pathogen and suspected to be a biocontrol species (22). Specifically, reduced symptoms of Verticillium wilt of potato and cauliflower have been associated with the presence of $V$. tricorpus in soil compared to soils with only pathogenic Verticillium species (8; S. C. França, M. Höfte, S. Pollet, and K. Spiessens, unpublished data). In addition,

Corresponding author: Jane Debode,

E-mail: jane.debode@ilvo.vlaanderen.be

J. Debode and K. Van Poucke contributed equally to this work.

Accepted for publication 11 July 2011.

doi:10.1094/PDIS-04-11-0267

(C) 2011 The American Phytopathological Society greenhouse and field experiments have demonstrated that $V$. tricorpus applied to soil can decrease symptoms caused by $V$. dahliae and $V$. albo-atrum on potato $(8,32)$. Reduced symptoms of Verticillium wilt were also observed in lettuce in a greenhouse experiment when $V$. dahliae was co-inoculated with $V$. tricorpus (30).

$V$. dahliae, V. longisporum, and V. tricorpus form microsclerotia, and these three species have been observed simultaneously in a cauliflower field in Belgium (S. C. França, J. Debode, B. Declercq, and M. Höfte, unpublished data). Microsclerotia are resting structures, agglomerates of thick-walled, melanized cells that can survive for more than 13 years in soil (34). Even low numbers of microsclerotia of $V$. dahliae and $V$. longisporum can lead to high levels of disease (3). For example, 1 microsclerotium/g soil can result in infection of more than 5 to $15 \%$ of the plants in crops of strawberry (16), cauliflower (39), and artichoke (3). Moreover, a small increase in the inoculum density to about 3 microsclerotia/g resulted in about $40 \%$ of infected artichoke plants, an incidence high enough to reduce yield (3). No reliable curative measures exist to control these pathogens other than soil fumigation, which is either restricted in several countries, not economically viable for many crops, or both. This increases the importance of accurate, preplanting assessment of the inoculum potential of a soil, especially considering the difference in the host ranges of $V$. dahliae and $V$. longisporum. In addition, simultaneous quantitative detection of $V$. tricorpus microsclerotia could further help in the evaluation of potential biological control activity by this species relative to the other two species in soil.

Several methods have been devised for quantifying Verticillium spp. in soil, including plating methods (dry and wet plating), bioassays, immunoassays, and molecular methods (reviewed by Goud and Termorshuizen [14]). The two semi-quantitative molecular methods for the detection of Verticillium spp. in soil are competitive polymerase chain reaction (PCR) $(24,25)$ and a macroarray (23). Immunoassays and bioassays are not often used; the plating methods are most commonly used. These involve plating a small 
amount of soil on a semi-selective medium, incubating the plates for several weeks, and then microscopically analyzing the fungal colonies on the medium. With dry plating assays, a small number of dry soil particles are distributed onto agar plates. Wet plating assays include wet sieving as a step to remove particles smaller and larger than microsclerotia. One of the most commonly used wet sieving techniques, described by Harris et al. (17), includes plating the wet sieved soil onto semi-selective modified soil extract agar (MSEA) medium. One limitation of this conventional technique is that morphological differentiation of the microsclerotia from different Verticillium species on MSEA medium is very labor-intensive and difficult. Although the morphological differentiation between $V$. tricorpus and $V$. dahliae on the MSEA medium has been described $(8,15)$, these two species may easily be confused by analysts. Moreover, microsclerotia from $V$. longisporum have no consistent morphological differences from those of typical $V$. dahliae strains (22). A second limitation is that the wet sieving method is usually restricted to small soil samples of 1.9 to $12.5 \mathrm{~g}$ (36), which limits the representativeness of the assay. A third limitation is that the assay includes air-drying of the soil, sieving the soil, and multi-week incubation of the soil on plates of agar medium, which together take 25 to 43 days to complete (36).

A DNA-based detection soil assay technique, such as real-time PCR, may offer an alternative for more specific and rapid detection of Verticillium species in soil than the wet sieving method. Recently, a real-time PCR assay specific for $V$. dahliae in potato tissue was developed (1), but its applicability to soil samples has not yet been demonstrated. To our knowledge, no real-time PCR detection method(s) specific for $V$. tricorpus and $V$. longisporum in soil has been described. PCR-based detection of Verticillium in soil requires DNA extraction from soil samples or from extracted microsclerotia. Commercially available DNA extraction kits can only process small soil sample volumes (usually $0.25 \mathrm{~g}$ and, exceptionally, up to $10 \mathrm{~g}$ of soil). These limited amounts are not representative for a whole field, and may result in false negative results, because as little as 1 microsclerotium/g of soil needs to be detected (3). Therefore, extraction of microsclerotia from soil, such as by the density flotation technique (18), should precede DNA extraction and may increase sensitivity of the assay.

The objectives of this study were: (i) to develop real-time PCR assays for specific detection and quantification of $V$. tricorpus and $V$. longisporum, and if need be, $V$. dahliae, that are applicable to soil samples, (ii) to develop a new method to detect and quantify microsclerotia of $V$. dahliae, $V$. longisporum, and $V$. tricorpus in soil using density flotation of soil followed by real-time PCR assays (DFS + real-time PCR), and (iii) to compare the results of the DFS + real-time PCR method with the results obtained after applying the conventional wet sieving method and after using real-time PCR analysis of DNA extracted directly from soil.

\section{Materials and Methods}

Fungal cultures and DNA extraction. DNA from $2 \mathrm{~V}$. alboatrum, $9 \mathrm{~V}$. dahliae, $11 \mathrm{~V}$. longisporum, and $5 \mathrm{~V}$. tricorpus isolates, and 11 non-Verticillium isolates was used to design and test realtime PCR primers (Table 1). All individual fungal isolates were grown in potato dextrose broth (PDB) for 2 weeks, and DNA was extracted from approximately $100 \mathrm{mg}$ fresh weight of mycelium per isolate (see below).

Microsclerotia of $V$. dahliae were obtained by collecting potato stems from a naturally infested field. Microsclerotia of $V$. longisporum strain $\mathrm{O} 1$ and $V$. tricorpus strain 305 were produced as described by Mol et al. (27) with modifications, then stored at $4^{\circ} \mathrm{C}$. Briefly, conidial suspensions of these two isolates were prepared by flooding potato dextrose agar (PDA) cultures with sterile water and rubbing the surface of each plate with a glass rod. The suspensions were filtered through autoclaved cheesecloth and the spore concentration was determined using a hemocytometer. Five autoclaved segments $(1.0$ to $1.5 \mathrm{~cm}$ ) of cauliflower petiole (cv. Cornell) were placed on MSEA medium, and each stem section was inoculated with $50 \mu \mathrm{l}$ of a spore suspension of the appropriate Verticil- lium species $\left(10^{5}\right.$ spores $\left./ \mathrm{ml}\right)$. Twenty days after incubation at $22^{\circ} \mathrm{C}$ in the dark, a large amount of microsclerotia had formed on each segment. Both cauliflower and potato segments were air-dried at room temperature and gently ground with a mortar and pestle. Sterile water was added and the microsclerotia concentration in the suspension was determined using a hemocytometer. Subsequently, the suspensions were serially diluted resulting in $10,50,500$, and $5,000 \mathrm{microsclerotia} / \mathrm{ml}$, and $1 \mathrm{ml}$ of each dilution was vacuum filtered $(20 \mu \mathrm{m}$; Millipore). DNA was extracted from the microsclerotia retained on the filter.

DNA was extracted from mycelium and conidia with the Invisorb Spin Plant Mini DNA extraction kit (Invitek) and from microsclerotia using the MoBio Power Soil DNA extraction kit (MoBio Laboratories) following the manufacturers' instructions. DNA concentrations of the samples were quantified using a Nanodrop spectrophotometer, and DNA was stored at $-20^{\circ} \mathrm{C}$ until needed.

Primer design. The rDNA ITS regions and the partial $\beta$-tubulin genes of isolates STR3 (V. albo-atrum), Ve005 (V. dahliae), Pf1 (V. longisporum), and $\mathrm{Ve} 010$ (V. tricorpus) (Table 1) were amplified by PCR using the universal primers ITS1/ITS4 (38) and T1/T2 (29), respectively. PCR was performed with FastStart Taq DNA polymerase (Roche) in a Geneamp PCR System 9700 (Applied Biosystems). An initial denaturation step at $94^{\circ} \mathrm{C}$ for 3 min was followed by 35 cycles of $30 \mathrm{~s}$ at $94^{\circ} \mathrm{C}, 30 \mathrm{~s}$ at $55^{\circ} \mathrm{C}$, and $1 \mathrm{~min}$ at $72^{\circ} \mathrm{C}$. After the last cycle, a final extension step at $72^{\circ} \mathrm{C}$ for $10 \mathrm{~min}$ was performed. The amplified fragments of expected size were purified using gel extraction with a NucleoSpin Extract II kit (Macherey-Nagel) and cloned in a pCRII-TOPO vector with the TOPO TA Cloning Kit (Invitrogen). DNA of the plasmid clones was extracted using a NucleoSpin plasmid DNA purification kit (Macherey-Nagel). The plasmid inserts were sequenced by Macrogen using primers Sp6 and T7.

The ITS sequences were deposited in GenBank (Table 1) and included in sequence alignments using Vector NTI's Align X module (Invitrogen), together with those of other Verticillium isolates already present in GenBank (V. albo-atrum: X60705, Z29508, Z29509, Z29523, and AF364014; $V$. dahliae: AJ865691, AJ970308, EF015891, Z29511, and Z29510; V. longisporum: AF364007, AY566605, and DQ266225; V. tricorpus: AF364017, AY555960, L28279, and Z29524). In addition, clones containing the partial $\beta$-tubulin gene were sequenced for $V$. albo-atrum (2 clones), $V$. dahliae (2 clones), $V$. longisporum (14 clones), and $V$. tricorpus (2 clones). For each species, a single sequence was obtained and deposited in GenBank, except for $V$. longisporum, for which two $\beta$-tubulin sequences were identified and deposited (Table 1). Other Verticillium $\beta$-tubulin sequences (DQ840570 to DQ840626 [5]) were included in the sequence alignments to design $V$. longisporum-specific primers.

Species-specific primers designed from areas polymorphic among species of the genus Verticillium, yet monomorphic within $V$. tricorpus, V. longisporum, or $V$. dahliae, were manually selected and evaluated for primer-dimer formation and self-annealing using the program Oligo Analyzer (Gene Link). Fifteen candidate primer pairs were tested in an initial screening through amplification and melting-curve analysis of real-time PCR reactions using DNA from 4 Verticillium isolates (STR3, Ve005, Pf1, and Ve010; Table 1). Subsequently, primer pairs VtF4/VtR2, VlTubF2/VlTubR1, and VdTubF2/VdTubR4 were selected for the detection of V. tricorpus, $V$. longisporum, and $V$. dahliae $+V$. longisporum (Table 2) and further evaluated for specificity using approximately $100 \mathrm{pg}$ DNA from all the isolates listed in Table 1. Amplification efficiency (= $\left.10^{(1 / \text {-slope })}-1\right)(13)$ and sensitivity of each primer pair was determined using a triplicate 10 -fold serial dilution of genomic DNA (10 to $1 \times 10^{6} \mathrm{fg}$ gDNA/5 $\mu \mathrm{l}$ ), and $5 \mu \mathrm{l}$ (out of $100 \mu \mathrm{l}$ ) DNA extracts from two serial dilutions of microsclerotia (see above). In addition to the development of primers for $V$. tricorpus, $V$. longisporum, and $V$. dahliae, the specificity of primer pairs VertBtF/VertBt-R (designed for $V$. dahliae detection in potato [1]) and OLG70/OLG71 (designed for V. dahliae and V. longisporum detection in oilseed rape [12]) were evaluated in this study. 
Real-time PCR. Real-time PCR was performed in 50- $\mu$ l reactions containing $5 \mu$ lemplate, $200 \mathrm{nM}$ of each primer (or $300 \mathrm{nM}$ of the $V$. tricorpus primers $\mathrm{VtF} 4 / \mathrm{VtR} 2$ ), and $25 \mu$ l Maxima SYBR Green master mix (Fermentas). Real-time PCR and melting curve analysis was performed using an ABI Prism 7900 HT Sequence Detection System (Applied Biosystems). The thermocycling profile consisted of $10 \mathrm{~min}$ at $95^{\circ} \mathrm{C}$ and 40 cycles of $15 \mathrm{~s}$ at $95^{\circ} \mathrm{C}$ and $1 \mathrm{~min}$ at $60^{\circ} \mathrm{C}$. Melting curve analysis was used to distinguish potential primer dimers and nonspecific amplification products.
Quantification was done using the standard curve technique with a 10 -fold dilution series of gDNA in sterile water $\left(10\right.$ to $1 \times 10^{6} \mathrm{fg} / 5$ $\mu \mathrm{l})$ from reference strains Ve005 (V. dahliae), Pf1 (V. longisporum), and $\mathrm{Ve} 010$ (V. tricorpus).

Conventional detection of Verticillium species in soil via the wet sieving method. To determine the number of viable microsclerotia in naturally infested soil samples, the wet sieving method described by Harris et al. (17) was used. Briefly, $12.5 \mathrm{~g}$ of dry soil was wet sieved, the 20 to $100 \mu \mathrm{m}$ fraction suspended in $0.08 \%$

Table 1. Name, origin, accession number, and source of the fungal isolates and oomycetes used in this study and Ct values of the real-time polymerase chain reaction (PCR) assays showing the specificity of primer pairs VtF4/VtR2, VlTubF2/VlTubR1, and VdTubF2/VdTubR4 used to detect Verticillium tricorpus, V. longisporum, and V. dahliae, respectively

\begin{tabular}{|c|c|c|c|c|c|c|c|c|}
\hline \multirow[b]{3}{*}{ Isolate name } & \multirow[b]{3}{*}{ Origin $^{a}$} & \multirow{3}{*}{$\begin{array}{l}\text { Geographic } \\
\text { origin }^{\mathrm{a}}\end{array}$} & & & \multirow[b]{3}{*}{ Source ${ }^{a}$} & \multicolumn{3}{|c|}{ Ct value $(\approx 100 \mathrm{pg})^{\mathrm{a}, \mathrm{b}, \mathrm{c}, \mathrm{d}}$} \\
\hline & & & \multicolumn{2}{|c|}{ Accession number } & & \multirow{2}{*}{$\begin{array}{l}\text { VtF4/ } \\
\text { VtR2 }\end{array}$} & \multirow{2}{*}{$\begin{array}{l}\text { VITubF2/ } \\
\text { VITubR1 }\end{array}$} & \multirow{2}{*}{$\begin{array}{l}\text { VdTubF2/ } \\
\text { VdTubR4 }\end{array}$} \\
\hline & & & ITS $^{a, e}$ & $\beta$-tubulin & & & & \\
\hline Verticillium albo-atrum VA1 & Solanum lycopersicum $\mathrm{L}$. & Netherlands & AF364014 & DQ840616-18 & (7) & $>40$ & $>40$ & $>40$ \\
\hline $\begin{array}{l}\text { V. albo-atrum STR3 } \\
\text { (Ve002) }\end{array}$ & Medicago sativa $\mathrm{L}$. & Canada & GQ495790 & GU564540 & (7) & $>40$ & $>40$ & $>40$ \\
\hline V. dahliae JKG1 & Solanum tuberosum L. & Netherlands & I & I & (20) & $>40$ & $>40$ & 26.7 \\
\hline V. dahliae JKG8 & S. tuberosum & Netherlands & l & l & (20) & $>40$ & $>40$ & 27.6 \\
\hline V. dahliae $\mathrm{Ve} 005$ & Soil & Belgium & GQ495791 & GU564541 & ILVO & $>40$ & $>40$ & 27.5 \\
\hline V. dahliae $\mathrm{Ve} 012$ & Soil & Belgium & 1 & l & ILVO & $>40$ & $>40$ & 27.6 \\
\hline V. dahliae VD73 & Linum usitatissimum $\mathrm{L}$. & Germany & I & I & $(12)$ & $>40$ & $>40$ & 24.3 \\
\hline V. dahliae ER1085 & Solanum melongena $\mathrm{L}$. & Italy & I & I & CRA-PAV & $>40$ & $>40$ & 29.2 \\
\hline V. dahliae ER1180 & $\begin{array}{l}\text { Hebe } \times \text { franciscana } \\
\text { (Eastw.) }\end{array}$ & Italy & l & l & CRA-PAV & $>40$ & $>40$ & 26.3 \\
\hline V. dahliae ER1606 & S. lycopersicum & Italy & I & I & CRA-PAV & $>40$ & $>40$ & 29.2 \\
\hline V. dahliae ER1352 & Olea europaea $\mathrm{L}$. & Italy & I & I & CRA-PAV & $>40$ & $>40$ & 27.4 \\
\hline V. longisporum $\mathrm{Be} 1$ & $\begin{array}{l}\text { Brassica oleracea var. } \\
\text { botrytis L. }\end{array}$ & Netherlands & AY566601 & I & (10) & $>40$ & 27.6 & 25.9 \\
\hline $\begin{array}{l}\text { V. longisporum } \mathrm{Pf} 1 \\
\text { (Ve007) }\end{array}$ & B. oleracea var. botrytis & Germany & GQ495792 & $\begin{array}{l}\text { GU564542 } \\
\text { GU564543 }\end{array}$ & $(10)$ & $>40$ & 28.5 & 27.4 \\
\hline V. longisporum $\mathrm{K} 1$ & B. oleracea var. botrytis & Belgium & AY566600 & 1 & (10) & $>40$ & 27.8 & 28.3 \\
\hline V. longisporum $\mathrm{Wvl} 2$ & B. oleracea var. botrytis & Belgium & AY566605 & I & (10) & $>40$ & 27.0 & 27.2 \\
\hline V. longisporum $\mathrm{O} 1$ & B. oleracea var. botrytis & Belgium & AY566606 & I & (10) & $>40$ & 27.3 & 27.5 \\
\hline$V$. longisporum $\mathrm{P} 4$ & B. oleracea var. botrytis & Belgium & AY566604 & I & (10) & $>40$ & 25.5 & 25.6 \\
\hline V. longisporum $\mathrm{S} 3$ & B. oleracea var. botrytis & Belgium & AY566603 & I & (10) & $>40$ & 25.4 & 25.4 \\
\hline V. longisporum VL43 & $\begin{array}{l}\text { B. napus L. subsp. } \\
\text { oleifera (Delile) }\end{array}$ & Germany & 1 & l & (12) & $>40$ & 29.6 & 25.3 \\
\hline V. longisporum VD1 & B. napus ssp. oleifera & Sweden & I & I & (35) & $>40$ & 31.8 & 23.5 \\
\hline V. longisporum VD4 & B. napus ssp. oleifera & Sweden & I & 1 & (35) & $>40$ & 27.6 & 23.9 \\
\hline V. longisporum VD11 & B. napus ssp. oleifera & Sweden & 1 & I & (35) & $>40$ & 30.0 & 26.0 \\
\hline V. tricorpus $\mathrm{Ve} 010$ & $\begin{array}{l}\text { Chrysanthemum } \times \\
\text { morifolium }\end{array}$ & Belgium & GQ495793 & GU564544 & ILVO & 23.5 & $>40$ & $>40$ \\
\hline V. tricorpus $\mathrm{Vt} 1$ & NK & NK & I & I & ILVO & 23.1 & $>40$ & $>40$ \\
\hline V. tricorpus $\mathrm{Vt} 2$ & NK & NK & i & i & ILVO & 23.2 & $>40$ & $>40$ \\
\hline V. tricorpus IIA & Soil & Belgium & I & I & ILVO & 23.0 & $>40$ & $>40$ \\
\hline V. tricorpus 305 & Soil & Belgium & I & I & UGent & - & - & - \\
\hline $\begin{array}{l}\text { Acremonium alternatum } \\
\text { PSKW01 }\end{array}$ & Capsicum аппиит $\mathrm{L}$. & Belgium & l & I & ILVO & $>40$ & $>40$ & $>40$ \\
\hline Alternaria solani ALT & NK & Belgium & l & l & ILVO & $>40$ & $>40$ & $>40$ \\
\hline $\begin{array}{l}\text { Aspergillus westerdijkiae } \\
\text { ASP }\end{array}$ & C. аппиит & Belgium & l & l & ILVO & $>40$ & $>40$ & $>40$ \\
\hline $\begin{array}{l}\text { Colletotrichum coccodes } \\
\text { PCF987 }\end{array}$ & $\begin{array}{l}\text { Fragaria } \times \text { ananassa } \\
\text { (Duch.) }\end{array}$ & Belgium & l & l & (37) & $>40$ & $>40$ & $>40$ \\
\hline $\begin{array}{l}\text { Fusarium oxysporum } \\
\text { dep2283 }\end{array}$ & $\begin{array}{l}\text { Apium graveolens } \mathrm{L} \text {. var. } \\
\text { rapaceum }\end{array}$ & Belgium & l & l & ILVO & $>40$ & $>40$ & $>40$ \\
\hline $\begin{array}{l}\text { Galactomyces geotrichum } \\
\text { KHK64 }\end{array}$ & C. аппиит & Belgium & l & l & ILVO & $>40$ & $>40$ & $>40$ \\
\hline $\begin{array}{l}\text { Penicillium roqueforti } \\
\text { PEN }\end{array}$ & NK & Belgium & l & l & ILVO & $>40$ & $>40$ & $>40$ \\
\hline $\begin{array}{l}\text { Phytophthora cinnamoni } \\
\text { Ph226 }\end{array}$ & Soil & Belgium & l & l & ILVO & $>40$ & $>40$ & $>40$ \\
\hline Pythium ultimит Ру034 & Cucumis sativus $\mathrm{L}$. & Bulgaria & I & I & ILVO & $>40$ & $>40$ & $>40$ \\
\hline Rhizoctonia solani RS & S. tuberosum & ILVO & 1 & I & ILVO & $>40$ & $>40$ & $>40$ \\
\hline $\begin{array}{l}\text { Trichoderma harzianum } \\
\text { TRI }\end{array}$ & NK & Belgium & l & l & ILVO & $>40$ & $>40$ & $>40$ \\
\hline
\end{tabular}

a NK = not known; ITS = rDNA internal transcribed spacer region sequence; ILVO = Instituut voor Landbouwen Visserij Onderzoek, Merelbeke, Belgium; CRA-PAV = Centro di Ricerca per la Patologia Vegetale, Rome, Italy; $\mathrm{Ct}=$ threshold cycle; UGent $=$ Ghent University.

$\mathrm{b}_{-}=$not analyzed.

${ }^{\mathrm{c}}$ Real-time PCR amplifications were conducted using $\approx 100$ pg DNA extracted from fungal mycelium of each isolate.

${ }^{\mathrm{d}} \mathrm{Ct}>40$ was considered as the cut-off value.

$\mathrm{e} / \mathrm{=}$ not available in GenBank. 
water agar $(50 \mathrm{ml})$, and $0.8 \mathrm{ml}$ of this suspension was spread on each of 10 petri dishes containing MSEA medium and incubated at $22^{\circ} \mathrm{C}$. After 4 weeks, soil particles were carefully washed from the plates and clusters of Verticillium microsclerotia were counted under a dissecting microscope. Morphological differentiation between $V$. tricorpus and $V$. dahliae/V. longisporum microsclerotia was based on Davis et al. (8) and Goud et al. (15).

New method of detection of Verticillium species in soil via DFS + real-time PCR. One hundred grams of air-dried artificially or naturally infested soil were crumbled with a mortar and pestle and thoroughly mixed with $100 \mathrm{ml} 70 \%$ (wt/wt) sucrose and centrifuged at $2,700 \times g$ for $20 \mathrm{~min}$ (24). The resulting supernatant was poured into a vacuum-filtration system (Gelman Sciences) over a $20-\mu \mathrm{m}$ nylon mesh filter (Millipore) and rinsed with sterile water. DNA was extracted from the material retained on the filter, using the MoBio Power Soil DNA isolation kit following the manufacturer's instructions. The material retained on the filter was always less than $0.25 \mathrm{~g}$. DNA was eluted in $100 \mu \mathrm{l}$ buffer, and $5 \mu \mathrm{l}$ of the DNA extract was used in the real-time PCR assays. When wet soil was analyzed (without the air-drying step), the soil sample weight used in the test was increased to compensate for the water content. The moisture content was first determined by oven-drying a subsample $(30 \mathrm{~g})$ overnight at $110^{\circ} \mathrm{C}$.

Analysis of inoculated soil samples using DFS + real time PCR. Inoculated soil samples were prepared by adding known numbers of $V$. longisporum, $V$. tricorpus, or $V$. dahliae microsclerotia to Verticillium-free soil. Microsclerotia prepared in aqueous suspensions (see above) were added to an autoclaved sandy-loam soil ( $\mathrm{pH}-\mathrm{KCl} 7.6,1.8 \% \mathrm{C}$ ) collected from a corn field in Merelbeke, Belgium, to densities of 0.1, 0.5, 5.0, and 50.0 microsclerotia/g dry soil. Two replicates of each soil sample were analyzed separately using DFS + real-time PCR with primer pairs specific for V. tricorpus, V. longisporum, and V. dahliae.

Analysis of naturally infested soil samples using DFS + realtime PCR versus the wet sieving method. The DFS + real-time PCR method was compared with the wet sieving method using 25 naturally infested soil samples from three types of field soils that were cropped with a specific host during the sampling year. First, during the autumn of 2009, soil samples were collected from the top 0 to $30 \mathrm{~cm}$ depth of two Belgian cauliflower fields. Ten soil samples were taken per field, along two diagonal transects within each field. The first cauliflower field (denoted as PSKW) was located in the province of Antwerp, Belgium (sandy-loam soil, $\mathrm{pH}-$ $\mathrm{KCl} 5.5,0.9 \% \mathrm{C}$ ), had been planted yearly for at least 7 years with cauliflower, and was associated with severe Verticillium wilt symptoms on cauliflower plants (cv. Cornell) during the growing season of 2007-2008. The second cauliflower field (denoted as POVLT) was located in the province of West Flanders, Belgium (sandyloam soil, $\mathrm{pH}-\mathrm{KCl} 5.6,0.8 \% \mathrm{C}$ ). This field was associated with moderate Verticillium wilt symptoms on cauliflower plants (cv. Clapton) during the growing season of 2007-2008, and in the last 20 years had been rotated five times with potato. The cauliflower cultivars planted in these fields in 2007-2008 are of comparable susceptibility to Verticillium (K. Spiessens and S. Pollet, unpublished data). Verticillium wilt severity and incidence on cauliflower were evaluated in each field based on vascular discoloration of the stem. Both composite soil samples were analyzed for the presence of Verticillium species using the wet sieving method and the DFS + real-time PCR method. For the latter method, the experiment con- sisted of two fixed factors: prehandling treatment and soil. Three prehandling treatments: (i) no drying of the soil, (ii) drying of the soil for 2 weeks, and (iii) storage of the soil for 2 weeks at $4{ }^{\circ} \mathrm{C}$, were applied to two soils (POVLT and PSKW), with three replicates per soil. One replicate consisted of the total DNA extracted from $100 \mathrm{~g}$ of soil using the DFS method. The prehandling treatments were included to evaluate whether drying the soil prior to analysis was necessary, and whether storing wet soil at $4^{\circ} \mathrm{C}$ had an influence on the amount of Verticillium DNA recovered. The primer pairs developed in this study that were specific for $V$. tricorpus, $V$. longisporum, and $V$. dahliae $+V$. longisporum were used in the real-time PCR analyses of these naturally infested soils.

Second, in the spring of 2010, soil samples were collected from the top 0 to $30 \mathrm{~cm}$ depth of an agricultural field in Merelbeke, Belgium (sandy-loam soil, $\mathrm{pH}-\mathrm{KCl} 6.0,0.8 \% \mathrm{C}$ ). This field (denoted as $\mathrm{Me}$ ) had been rotated with monocotyls (ryegrass and wheat) in 2006 and 2007 and later with flax (2008) and potatoes (2009). In 2010, it was divided into 32 experimental plots of $11 \times 15 \mathrm{~m}$. Per plot, 8 soil samples were taken, thoroughly mixed, dried for 2 weeks, and stored at room temperature. In a preliminary experiment, the non-species-specific number of Verticillium microsclerotia was analyzed in samples from each plot using the wet sieving method. In January 2011, 11 plots (A1, A4, B5, B6, C5, C7, C8, D1, D3, D4, and D7) with varying levels of total numbers of Verticillium microsclerotia were selected for further analysis using the wet sieving method as well as the DFS + real-time PCR method. In total, 10 replicate plates were used for the wet sieving method (12.5 $\mathrm{g}$ total), and two replicate samples of $100 \mathrm{~g}$ were used for DFS + real-time PCR.

The third set of soil samples was collected in July to September 2009 from the top (0 to $30 \mathrm{~cm}$ ) and the deeper $(30$ to $60 \mathrm{~cm}$ ) soil layers of two flax fields in France at three time points/field. Four soil samples were taken per field, time point, and depth, thoroughly mixed, and stored at room temperature until analysis. In the first field (located in the province of Calvados; denoted as S3), no Verticillium symptoms were observed in 2009. In the second field (located in the province of Oise and denoted as S8), severe Verticillium symptoms were observed in 2009. The soil samples were analyzed using the wet sieving and DFS + real-time PCR methods in January 2011. In total, 10 replicate plates were used for the wet sieving method (12.5 g total), and two replicate samples of $100 \mathrm{~g}$ were used for the density flotation method followed by real-time PCR.

Analysis of naturally infested soil samples using DFS + realtime PCR versus direct DNA extraction + real-time PCR. In March 2011, soil samples were collected from the top 0 to $10 \mathrm{~cm}$ depth of each plot of the Me field (see above). Soil samples from 5 plots were selected (A1, A6, A8, C5, and D7) and analyzed by realtime PCR using primer pair VdTubF2/VdTubR4, and DNA extracted (i) directly from $0.025 \mathrm{~g}$ of soil using the MoBio Power Soil kit, (ii) directly from $10 \mathrm{~g}$ of soil using the MoBio UltraClean Mega Soil kit, and (iii) from the material retrieved on the filter after density flotation of $100 \mathrm{~g}$ of soil using the MoBio Power Soil kit (the DFS + real-time PCR method, see above). For each method, duplicate samples were analyzed and $5 \mu \mathrm{l}$ of the resulting DNA samples was used for real-time PCR analysis.

Assessment of PCR inhibitors. The presence of PCR inhibitors in DNA samples extracted from soil samples collected in 2010 from the Me field was assessed by: (i) 10-fold diluting the DNA

Table 2. Names, sequences, and location of the primers developed to detect and quantify Verticillium spp. in soil

\begin{tabular}{llllcc}
\hline Target organism & Gene target & Primer & Sequence (5' to 3') & Locationa & Amplicon size (bp) \\
\hline V. tricorpus & rDNA ITS & VtF4 & CCGGTGTTGGGGATCTACT & $337-355$ & 123 \\
& & VtR2 & GTAGGGGGTTTAGAGGCTG & $441-459$ & $374-394$ \\
V. longisporum & $\beta$-tubulin & VlTubF2 & GCAAAACCCTACCGGGTTATG & 143 \\
V. dahliae + V. longisporum & $\beta$-tubulin & VlTubR1 & AGATATCCATCGGACTGTTCGTA & $215-235$ & 82 \\
& & VdTubF2 & GGCCAGTGCGTAAGTTATTCT & $276-296$ \\
\hline
\end{tabular}

a Based on accession numbers GQ495793, GU564543, and GU564541, for V. tricorpus, V. longisporum, and V. dahliae + V. longisporum, respectively. 
samples and (ii) spiking each DNA sample and a water control with $10^{4}$ pDNA copies containing the rDNA ITS region of Colletotrichum acutatum isolate NI90, and analyzing them using a $C$. acutatum-specific real-time PCR assay (11). The shift in $\mathrm{Ct}$ value after diluting $\left(\Delta \mathrm{Ct}_{\text {dilution }}=\mathrm{Ct}_{1 / 10}-\mathrm{Ct}_{1 / 1}\right)$ was compared with the theoretical shift in the absence of PCR-inhibition, being the slope of the standard curve based on pure $V$. dahliae gDNA. For the spiked samples, the $\mathrm{Ct}$ values attributed to the $C$. acutatum DNA in the sample background versus in water were compared. If no PCR inhibiting compounds are present in the samples, then $\Delta \mathrm{Ct}_{\text {spiked }}=$ $\mathrm{Ct}_{\text {sample }}-\mathrm{Ct}_{\text {water control }}$ is expected to be not significantly different from zero.

Statistical analysis. The relationship between the results of the wet sieving and the DFS + real-time PCR method was analyzed using linear regression. The effects of pretreatments and soil origin (cauliflower fields POVLT versus PSKW) were analyzed using ANOVA. The data relating to the presence of inhibitors were analyzed using $t$ tests. The effects of soil origin (flax fields S3 versus S8) were also analyzed using a $t$ test, after $\log$-transformation of the amounts of Verticillium DNA/g soil to normalize the data. All tests were conducted using STATISTICA 9.0 (Statsoft).

\section{Results}

Primer design and evaluation. The ITS2 regions of the $V$. tricorpus isolates were clearly divergent from the ITS2 regions of isolates of the three other Verticillium species evaluated (V. tricorpus versus $V$. albo-atrum, $V$. dahliae, and $V$. longisporum: 2.6, 3.5, and $2.6 \%$ divergent or $12 / 456 \mathrm{bp}, 16 / 459 \mathrm{bp}$, and $12 / 459 \mathrm{bp}$ differences, respectively) and therefore were used to design specific primers for $V$. tricorpus. Four primer pairs were tested. Primer pair $\mathrm{VtF} 4 / \mathrm{VtR} 2$ (Table 2) was selected for further research, as it produced the lowest $\mathrm{Ct}$ values, resulted in a single fragment based on melting curve analysis, and showed a linear relationship with neartheoretical slope between the $\mathrm{Ct}$ values and the log values of the DNA concentration $\left(y=-3.37 x+40.54, R^{2}=0.98\right.$, amplification efficiency $=0.98$ ) when using a triplicate 10 -fold serial dilution of gDNA (10 to $1 \times 10^{6} \mathrm{fg}$ ) of $V$. tricorpus strain Ve010. Subsequently, approximately $100 \mathrm{pg}$ of gDNA of 37 isolates were included in the SYBR Green real-time PCR assay to further test specificity of the selected primer pair. Primer pair VtF4/VtR2 allowed the detection of the four $V$. tricorpus strains only, with a mean $\mathrm{Ct}$ value $\pm \mathrm{SE}$ of $23.2 \pm 0.1$ (Table 1 ).

The $\beta$-tubulin gene of the different Verticillium species was sequenced partially. Per strain, the clones had identical sequences, except for $V$. longisporum strain Pf1, for which the 14 clones had two sequences. The sequences of 7 of the 14 clones were identical to the $V$. dahliae sequence, and the sequence of the other 7 clones was specific for $V$. longisporum. A total of four primer pairs was tested, but only primer pair VlTubF2/VlTubR1 was selected for further analysis (Table 2), as this was the only primer pair specific for $V$. longisporum; furthermore, the melting curve analysis indicated the presence of a single amplification product. The relation between $\mathrm{Ct}$ values and log values of the DNA concentration was linear $\left(y=-3.32 x+44.98, R^{2}=0.99\right.$, amplification efficiency $=$ 1.00), using a triplicate 10-fold serial dilution of gDNA from 100 to $1 \times 10^{6} \mathrm{fg}$ from $V$. longisporum strain Pf1. Further specificity testing, with approximately $100 \mathrm{pg}$ gDNA of the 37 isolates listed in Table 1, showed that primer pair VlTubF2/VlTubR1 allowed specific detection of each of the $11 \mathrm{~V}$. longisporum strains, with a mean $\mathrm{Ct}$ of $28.0 \pm 0.2$ (Table 1 ).

Primer pair VertBt-F/VertBt-R, published by Atallah et al. (1), amplified part of the $\beta$-tubulin gene of both $V$. dahliae Ve005 and $V$. longisporum Pf1, but not of $V$. albo-atrum STR3 or $V$. tricorpus $\mathrm{Ve} 010$. As this primer pair only amplified $V$. dahliae and V. longisporum gDNA, it was initially selected for detection of V. dahliae + $V$. longisporum in our assays. However, in a later stage of the project, occasional nonspecific amplification was observed when using this primer pair with DNA extracted from soil samples. Specifically, melting curve analysis consistently showed the presence of a second amplicon when DNA extracted from some of the samples of the naturally infested soil from the Me field was used as template. Cloning and sequencing of this fragment revealed that primer VertBt-R by itself was able to amplify a 450-bp fragment of DNA of an unknown organism, which apparently limits the usefulness of the primers of Atallah et al. (1) for some soils. Primer pair OLG70/OLG71, published by Eynck et al. (12), amplified DNA of $V$. albo-atrum STR3, V. dahliae Ve005, V. longisporum $\mathrm{Pf} 1$, and $V$. tricorpus Ve010. As this primer pair was not species-specific, it was not a useful alternative. We therefore developed new primers based on the $\beta$-tubulin sequence alignment of the different Verticillium species. Out of seven candidate primer pairs, we selected primer VdTubF2/VdTubR4 based on specific and selective amplification of $V$. dahliae Ve005 and $V$. longisporum Ve Pf1 DNA (Table 2). The relation between $\mathrm{Ct}$ values and $\log$ values of the DNA concentration was linear $\left(y=-3.41 x+41.28, R^{2}=0.99\right.$, amplification efficiency $=0.96$ ), using a triplicate 10 -fold serial dilution of gDNA from 10 to $1 \times 10^{6} \mathrm{fg}$ from $V$. dahliae strain Ve005. Further specificity tests showed that primer pair VdTubF2/VdTubR4 allowed detection of the $9 \mathrm{~V}$. dahliae and $11 \mathrm{~V}$. longisporum strains with a mean $\mathrm{Ct}$ value of $27.3 \pm 0.1$ and $26.0 \pm 0.1$, respectively (Table 1), but not the other fungal species tested.

Detection limits. Assays including small amounts of template DNA (10 to $10^{6} \mathrm{fg}$ ) and DNA extracted from serial dilutions of $V$. tricorpus microsclerotia $(10,50,500$, and 5,000 microsclerotia) revealed that the primer pair $\mathrm{VtF} 4 / \mathrm{VtR} 2$ reliably detected as little as $10 \mathrm{fg}$ gDNA, or 0.5 microsclerotia per PCR reaction (mean $\mathrm{Ct}$ values of $38.1 \pm 0.2$ and $32.0 \pm 0.1$, respectively) using $1 / 20$ of the total DNA extracted from 10 microsclerotia $(5 \mu \mathrm{l}$ out of $100 \mu \mathrm{l})$. Similar assays with $V$. longisporum revealed that primer pair VlTubF2/VITubR1 reliably detected 100 fg DNA, or 2.5 microsclerotia of $V$. longisporum per PCR reaction (mean $\mathrm{Ct}$ values of $39.4 \pm 0.2$ and $34.1 \pm 0.2$, respectively). Primer pair VdTubF2/ VdTubR4 reliably detected $100 \mathrm{fg}$ gDNA or 0.5 microsclerotia (mean Ct values of $36.4 \pm 0.2$ and $33.8 \pm 0.2$, respectively).

Detection of Verticillium in artificially inoculated soil samples. Soil samples inoculated with V. tricorpus microsclerotia were analyzed using DFS + real-time PCR and primer pair VtF4/VtR2. Detection was successful starting from 0.1 microsclerotia/g soil $(\mathrm{Ct}$ of 34.9), and a linear relationship was observed between the log concentration of $V$. tricorpus microsclerotia added to the soil and the $\log$ concentration of $V$. tricorpus DNA detected (Fig. 1). The theoretical detection limit (at a $\mathrm{Ct}$ of 40) was at 0.002 microsclerotia/g soil. Soil samples inoculated with $V$. longisporum and $V$.

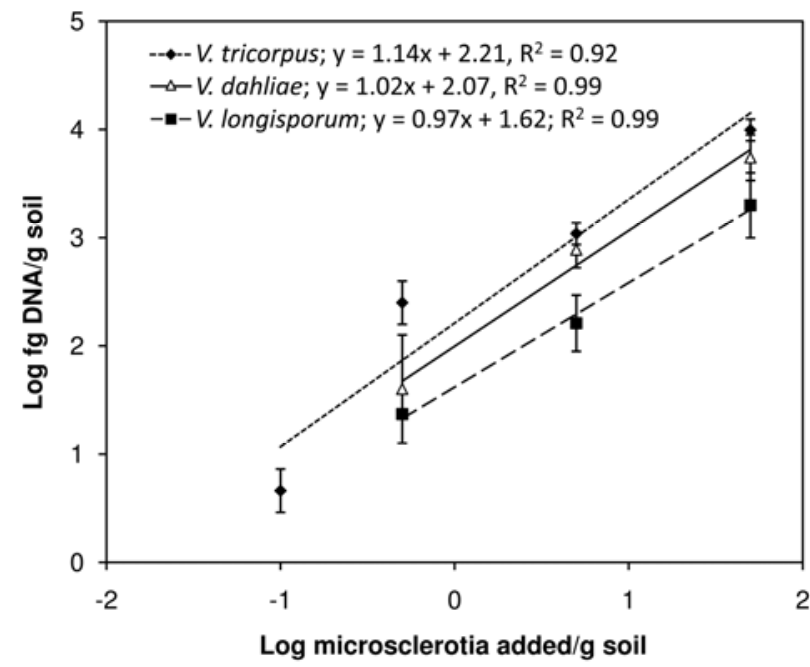

Fig. 1. Quantitative detection of Verticillium in soil inoculated with microsclerotia and then assayed using the real-time polymerase chain reaction (PCR) assays with primer sets VtF4/NtR2 for Verticillium tricorpus, VITubF2/VITubR1 for V. longisporum, and VdTubF2NdTubR4 for $V$. dahliae. Log-transformed concentrations of Verticillium DNA detected are plotted versus the log-transformed concentrations of Verticillium microsclerotia/g soil for each species. Error bars indicate standard errors of the mean. Each data point is the mean of two independent observations. 
dahliae microsclerotia were also analyzed using DFS + real-time PCR, but with primer pairs VlTubF2/VlTubR1 and VdTubF2/ VdTubR4, respectively. Detection of target DNA started at 0.5 microsclerotia/g soil (Ct of 37.2 and 36.2, respectively), and the $\log$ concentration of microsclerotia added to the soil and the $\log$ concentration of Verticillium DNA were highly correlated (Fig. 1). The theoretical detection limit (at a $\mathrm{Ct}$ of 40 ) was 0.02 and 0.04 microsclerotia/g soil, respectively. Using the linear regression lines shown in Figure 1 to convert fg DNA/g soil into microsclerotia/g soil, it was calculated that $1 \mathrm{microsclerotium} / \mathrm{g}$ soil corresponded to $41.7 \mathrm{fg}$ DNA/g soil for $V$. longisporum, $117.5 \mathrm{fg}$ DNA/g soil for $V$. dahliae, and $162.2 \mathrm{fg}$ DNA/g soil for $V$. tricorpus.

Detection of Verticillium in naturally infested soil samples using DFS + real-time PCR versus direct DNA extraction from soil + real-time PCR. Five naturally infested soil samples were analyzed by real-time PCR using primer pair VdTubF2/VdTubR4 and DNA extracted directly from $0.025 \mathrm{~g}$ and $10 \mathrm{~g}$ of soil (i and ii, respectively) and DNA extracted from material left on the filter after density flotation of $100 \mathrm{~g}$ of soil (DFS + real-time PCR method) (iii).

For the MoBio Power Soil kit (methods i and iii), DNA was eluted in $100 \mu \mathrm{l}$, of which $5 \mu \mathrm{l}$ was used per PCR reaction. Thus, $0.0125 \mathrm{~g}$ and $5.0 \mathrm{~g}$ soil equivalent was analyzed per PCR reaction (Table 3). For the UltraClean Mega Soil kit (method ii), DNA of 10 $\mathrm{g}$ of soil was eluted in $8 \mathrm{ml}$. As $5 \mu \mathrm{l}$ also was used in the PCR reaction, the soil equivalent analyzed was $0.00625 \mathrm{~g}$ (Table 3). Realtime PCR melting curve analysis of all 5 soil samples showed that only the target sequences were amplified.

For method (i), there was detection in only two of the five samples with a range of $<800$ to $5,329 \mathrm{fg} V$. dahliae $+V$. longisporum DNA/g soil (Table 3 ). The mean coefficient of variation $(C V) \pm S E$ for the two soil samples was $0.99 \pm 0.43$. For method (ii), there was only detection in three of the five samples with a range of $<1,600$ to11,071 fg V. dahliae + V. longisporum DNA/g soil (Table 3 ), and the mean $\mathrm{CV} \pm \mathrm{SE}$ for the 3 soil samples was $1.28 \pm 0.23$. For method (iii), there was detection in all six soil samples with a range of 40 to $353 \mathrm{fg} V$. dahliae $+V$. longisporum DNA/g soil (Table 3 ). The mean $\mathrm{CV} \pm \mathrm{SE}$ for the five soil samples was $0.60 \pm$ 0.44 .

Detection of Verticillium in naturally infested soil samples using DFS + real-time PCR versus the wet sieving method. Analysis of 25 naturally infested soil samples from three types of fields using the wet sieving method showed that the range of microsclerotia/g of naturally infested soil was 0.0 to 86.9 for $V$. tricorpus and 0.0 to 62.7 for $V$. dahliae $+V$. longisporum (Table 4). Using DFS + real-time PCR, the range of fg DNA/g soil was 1.9 to 86.7 for $V$. tricorpus and 39.0 to 9932.7 for V. dahliae $+V$. longisporum (Table 4). In addition, there was a significant linear relationship between the number of $V$. tricorpus microsclerotia/g soil and the amount of $V$. tricorpus DNA/g soil $\left(P=0.0001, R^{2}=0.78\right)$. This contrasted with $V$. dahliae $+V$. longisporum, where no linear relationship was found between the wet sieving method and the DFS + real-time PCR method $\left(P=0.79, R^{2}=0.0032\right)$. Melting curve analysis of all 25 soil samples showed that only the target sequences were amplified. The mean $\mathrm{CV} \pm \mathrm{SE}$ for the 25 soil samples was $0.30 \pm 0.03$ for $V$. tricorpus and $0.41 \pm 0.05$ for $V$. dahliae. $V$. longisporum was detected in only 1 of the 25 soil samples, with a CV of 0.10 .

Soil samples collected from two cauliflower fields naturally infested with Verticillium spp. were analyzed using the wet sieving method and the DFS + real-time PCR method. Using this latter method, three soil pretreatments (drying, no drying, and storage at $4^{\circ} \mathrm{C}$ ) were applied to both soil samples. Analysis of variance showed that there was no significant pretreatment effect and no significant pretreatment $\times$ soil interaction effect using the real-time PCR assays for $V$. tricorpus, $V$. longisporum, and $V$. dahliae $+V$. longisporum (Table 5). Therefore, the results of the prehandling treatments were pooled. Both the wet sieving and DFS + real-time PCR method showed that in the POVLT field, significantly more $V$. tricorpus and $V$. dahliae/V. longisporum propagules were present than in the PSKW field (Tables 3 and 5). In addition, real-time PCR analysis showed that the 4.4 microsclerotia/g soil detected with the wet sieving method in the PSKW soil were V. longisporum microsclerotia, whereas the 62.7 microsclerotia/g POVLT soil were V. dahliae microsclerotia (Table 4).

Analysis of naturally infested soil samples from the Me field using the wet sieving and the DFS + real-time PCR method showed that both $V$. dahliae and $V$. tricorpus were present in these samples. All DNA detected using real-time PCR and the $V$. dahliae $+V$. longisporum primers (VdTubF2/VdTubR4) could be attributed to $V$. dahliae, as there was no detection with the $V$. longisporum primers (VlTubF2/VlTubR1). Using the $V$. dahliae primers, the mean \pm $\mathrm{SE} \Delta \mathrm{Ct}_{\text {dilution }}$ of the soil samples was $3.0 \pm 0.3$ and not significantly different from the slope of the standard curve $(P=0.53)$. The mean $\Delta \mathrm{Ct}_{\text {spiked }}$ was very low: $0.2 \pm 0.1$, but significantly different from 0 $(P=0.001)$.

Analysis of naturally infested soil samples from the French flax fields showed that both $V$. dahliae and $V$. tricorpus were present in both soils, whereas no V. longisporum DNA was detected (Table 3). The amount of $V$. tricorpus found in these soils using both the wet sieving and the DFS + real-time PCR method was very low (1.1 microsclerotia/g soil and $11.3 \mathrm{fg} \mathrm{DNA} / \mathrm{g}$ soil on average). Remarkably, for $V$. dahliae, the wet sieving method gave very low microsclerotia counts (mean of 1.3 microsclerotia/g soil), especially compared to the amount of $V$. dahliae DNA detected with the molecular test (mean of $1314.1 \mathrm{fg}$ DNA/g soil) (Table 3). Statistical analysis of the molecular data showed that the amount of $V$. dahliae DNA in the symptomatic S8 field was significantly higher than in the nonsymptomatic S3 field $(P=0.001)$. No significant differences were found between the S3 and S8 fields in the amount of $V$. tricorpus DNA/g soil $(P=0.35)$.

\section{Discussion}

In this study, we developed a new method for quantifying microsclerotia-forming Verticillium species in soil that is specific, sensitive, and faster than the widely used wet sieving method. One of the main advantages of the new method is that it allows differentiation between $V$. dahliae and $V$. longisporum. This differentiation has not been possible previously, neither with conventional plating methods nor with previously published real-time PCR assays $(1,12)$. Although historically there has been a lack of agreement on

Table 3. Quantities of Verticillium dahliae + V. longisporum in five naturally infested soil samples (labeled A1 through D7) using direct DNA extraction from 0.25 and $10.0 \mathrm{~g}$ of soil and density flotation of $100 \mathrm{~g}$ of soil, all followed by real-time polymerase chain reaction analysis using primer pair VdTubF2/VdTubR4

\begin{tabular}{|c|c|c|c|c|c|c|c|c|}
\hline \multirow[b]{2}{*}{ Methoda $^{a}$} & \multirow{2}{*}{$\begin{array}{c}\text { Soil per } \\
\text { sample (g) }\end{array}$} & \multirow{2}{*}{$\begin{array}{l}\text { Soil equivalent per } \\
\text { PCR reaction (g) }\end{array}$} & \multirow{2}{*}{$\begin{array}{c}\text { Detection } \\
\text { limit (fg/g soil) }\end{array}$} & \multicolumn{5}{|c|}{ DNA quantity $(f g \mathrm{Vd}+\mathrm{VI}$ DNA/g soil $) \pm \mathrm{SE}$} \\
\hline & & & & $\mathbf{A 1}$ & A6 & $\mathbf{A 8}$ & C5 & D7 \\
\hline MoBio Power Soil & 0.25 & 0.0125 & 800 & $\mathrm{ND}^{\mathrm{b}}$ & $5,189 \pm 5,189 * c$ & $5,329 \pm 2,131$ & ND & ND \\
\hline $\begin{array}{l}\text { MoBio UltraClean } \\
\text { Mega Soil }\end{array}$ & 10 & 0.00625 & 1,600 & ND & $11,071 \pm 7,949$ & $1,625 \pm 1,625^{*}$ & ND & $1,184 \pm 1,184 *$ \\
\hline $\begin{array}{l}\text { DFS + } \\
\text { MoBio Power Soil }\end{array}$ & 100 & 5 & 2 & $353 \pm 269$ & $61 \pm 23$ & $220 \pm 70$ & $269 \pm 70$ & $40 \pm 1$ \\
\hline
\end{tabular}

${ }^{\mathrm{a}} \mathrm{DFS}=$ density flotation of soil.

${ }^{\mathrm{b}} \mathrm{ND}=$ No detection $(\mathrm{Ct}>40$ for both replicate samples).

$\mathrm{c} *=$ One of the two replicate samples had a Ct value $>40$ (under the detection limit). A value of $0 \mathrm{fg} \mathrm{Vd}+\mathrm{Vl} \mathrm{DNA} / \mathrm{g}$ soil was used for this sample. 
whether the long-spored $V$. longisporum strains are distinct species (22), recent analyses have established that they are of hybrid origin and most likely belong to a distinct species (19). Especially from a pathological point of view, it is very important to be able to differentiate between these species. This was illustrated in the present study in the experiment with naturally infested soil collected from two cauliflower fields. Real-time PCR analysis showed that the large amount of $V$. dahliae/ $V$. longisporum microsclerotia found in the POVLT soil with the wet sieving method was $V$. dahliae. This species was probably introduced with or stimulated by the potato crop and is less pathogenic to cauliflower than V. longisporum (9), resulting in a lower disease incidence. The number of $V$. dahliae + $V$. longisporum microsclerotia and the total amount of Verticillium DNA was much lower in the PSKW soil than in the POVLT soil, but these microsclerotia could be attributed to $V$. longisporum, which is much more pathogenic to crucifers (19). The lower disease incidence in the POVLT soil than in the PSKW soil can also be attributed to the high amounts of $V$. tricorpus microsclerotia detected, which were probably also introduced with or stimulated by the potato crop (8). V. tricorpus is nonpathogenic for many crops, including cauliflower (22; S. C. França, L. Tyvaert, and M. Höfte, unpublished data), and has potential biocontrol activity against pathogenic Verticillium species $(8,30,32)$.
Because of the hybrid nature of $V$. longisporum isolates (19), development of primers for $V$. longisporum was not easily done without also detecting isolates of $V$. dahliae. We sequenced 14 clones containing a part of the $\beta$-tubulin gene of one $V$. longisporum isolate, and our findings are in agreement with Clewes et al. (5) and Collado-Romero et al. (6), who reported the presence of multiple (two or three) sequences of the $\beta$-tubulin gene in $V$. longisporum isolates, but not in $V$. dahliae isolates. One of these sequences is similar to that of $V$. dahliae, while the other sequence presumably originated from an as-yet-unknown species. The $V$. longisporum primers were designed based on the sequence of the $\beta$-tubulin gene of this unknown species. Given the lack of knowledge about this unknown species and its potential pathogenicity, one can state that there might be a risk that the PCR primers developed in this study could also amplify DNA of this unknown species as well as those of $V$. longisporum, which could lead to overestimation of the amount of this species in soils. However, there are no indications that this unknown species is present in soil at concentrations that would interfere with the detection of $V$. longisporum. In the naturally infested soils analyzed in this study as well as in individual samples from several other soils (data not shown), we never encountered a detection signal with the $V$. longisporum primers in the absence of a signal with the $V$. dahliae primers. Once the primers

Table 4. Quantities of Verticillium tricorpus (Vt), V. dahliae (Vd), and V. longisporum (Vl) in 25 naturally infested soil samples using the wet sieving method and the density flotation of soil (DFS) + real-time polymerase chain reaction (PCR) method using primers sets VtF4/VtR2,VdTubF2/VdTubR4, and VlTubF2/VlTubR1, respectively

\begin{tabular}{|c|c|c|c|c|c|c|c|c|c|c|c|c|c|c|c|}
\hline \multirow[b]{3}{*}{ Field $^{f}$} & \multirow[b]{3}{*}{ Plot $^{\mathrm{g}}$} & \multirow[b]{3}{*}{ Crop $^{h}$} & \multirow{3}{*}{$\begin{array}{c}\text { Sampling } \\
\text { date } \\
(\mathbf{d} / \mathbf{m} / \mathbf{y})^{\mathbf{i}}\end{array}$} & \multirow{3}{*}{$\begin{array}{c}\text { Analyses } \\
\text { date } \\
(\mathbf{m} / \mathbf{y})^{\mathbf{i}}\end{array}$} & \multicolumn{5}{|c|}{ Verticillium wilt symptoms ${ }^{\mathrm{a}, \mathrm{b}, \mathrm{c}}$} & \multirow[b]{3}{*}{ Depth $^{j}$} & \multirow{2}{*}{\multicolumn{2}{|c|}{$\begin{array}{l}\text { Wet sieving }{ }^{d} \text { (micro- } \\
\text { sclerotia/g soil) } \pm S E\end{array}$}} & \multirow{2}{*}{\multicolumn{3}{|c|}{$\begin{array}{c}\text { DFS + real-time } P_{C R}{ }^{e} \\
(\text { fg DNA/g soil }) \pm S E\end{array}$}} \\
\hline & & & & & \multicolumn{2}{|c|}{ Incidence } & \multicolumn{3}{|c|}{ Severity } & & & & & & \\
\hline & & & & & 2007 & 2008 & 2007 & 2008 & 2009 & & Vt & $V d+V l$ & $\mathrm{Vt}$ & $V d+V l$ & Vl \\
\hline POVLT & - & $\begin{array}{l}\text { Brassica oleracea } \\
\text { var. botrytis }\end{array}$ & $27 / 08 / 09$ & 08-09/09 & $30 \%$ & $30 \%$ & $60 \%$ & $70 \%$ & - & 1 & $53.9 \pm 9.4$ & $62.7 \pm 9.4$ & $43.4 \pm 3.7$ & $1816.2 \pm 485.0$ & $<20.0$ \\
\hline PSKW & - & $\begin{array}{l}\text { B. oleracea var. } \\
\text { botrytis }\end{array}$ & $10 / 09 / 09$ & 09/09 & $60 \%$ & $70 \%$ & $90 \%$ & $100 \%$ & - & 1 & $<0.6$ & $4.4 \pm 2.7$ & $1.9 \pm 0.9$ & $272.7 \pm 21.0$ & $\begin{array}{c}204.5 \pm \\
7.8\end{array}$ \\
\hline $\mathrm{Me}$ & A1 & $\begin{array}{l}\text { Solanum } \\
\text { tuberosum }\end{array}$ & $13 / 04 / 10$ & $01 / 11$ & - & - & - & - & - & 1 & $12.1 \pm 1.9$ & $0.6 \pm 0.3$ & $5.8 \pm 0.4$ & $82.0 \pm 10.1$ & $<20.0$ \\
\hline $\mathrm{Me}$ & A4 & S. tuberosum & $13 / 04 / 10$ & $01 / 11$ & - & - & - & - & - & 1 & $29.7 \pm 2.8$ & $2.8 \pm 1.3$ & $8.5 \pm 1.3$ & $199.9 \pm 11.9$ & $<20.0$ \\
\hline $\mathrm{Me}$ & B5 & S. tuberosum & $13 / 04 / 10$ & $01 / 11$ & - & - & - & - & - & 1 & $8.3 \pm 1.9$ & $6.1 \pm 2.8$ & $25.5 \pm 0.3$ & $127.4 \pm 2.1$ & $<20.0$ \\
\hline $\mathrm{Me}$ & B6 & S. tuberosum & $13 / 04 / 10$ & $01 / 11$ & - & - & - & - & - & 1 & $5.0 \pm 1.3$ & $1.1 \pm 0.6$ & $30.6 \pm 11.3$ & $166.4 \pm 48.6$ & $<20.0$ \\
\hline $\mathrm{Me}$ & $\mathrm{C} 5$ & S. tuberosum & $13 / 04 / 10$ & $01 / 11$ & - & - & - & - & - & 1 & $40.2 \pm 6.6$ & $7.7 \pm 2.2$ & $43.1 \pm 8.0$ & $492.0 \pm 202.1$ & $<20.0$ \\
\hline $\mathrm{Me}$ & $\mathrm{C} 7$ & S. tuberosum & $13 / 04 / 10$ & $01 / 11$ & - & - & - & - & - & 1 & $64.9 \pm 3.8$ & $20.6 \pm 3.4$ & $38.2 \pm 1.4$ & $80.6 \pm 5.9$ & $<20.0$ \\
\hline $\mathrm{Me}$ & $\mathrm{C} 8$ & S. tuberosum & $13 / 04 / 10$ & $01 / 11$ & - & - & - & - & - & 1 & $49.5 \pm 4.1$ & $3.9 \pm 1.6$ & $47.4 \pm 11.3$ & $484.6 \pm 61.7$ & $<20.0$ \\
\hline $\mathrm{Me}$ & D1 & S. tuberosum & $13 / 04 / 10$ & $01 / 11$ & - & - & - & - & - & 1 & $86.9 \pm 5.0$ & $33.0 \pm 3.4$ & $76.1 \pm 13.3$ & $386.5 \pm 41.9$ & $<20.0$ \\
\hline $\mathrm{Me}$ & D3 & S. tuberosum & $13 / 04 / 10$ & $01 / 11$ & - & - & - & - & - & 1 & $66.1 \pm 7.8$ & $6.6 \pm 2.2$ & $86.7 \pm 9.0$ & $376.5 \pm 227.7$ & $<20.0$ \\
\hline $\mathrm{Me}$ & D4 & S. tuberosum & $13 / 04 / 10$ & $01 / 11$ & - & - & - & - & - & 1 & $47.8 \pm 6.6$ & $3.9 \pm 1.3$ & $71.1 \pm 9.1$ & $325.4 \pm 76.7$ & $<20.0$ \\
\hline $\mathrm{Me}$ & D7 & S. tuberosum & $13 / 04 / 10$ & $01 / 11$ & - & - & - & - & - & 1 & $64.4 \pm 5.3$ & $19.3 \pm 4.1$ & $67.8 \pm 18.6$ & $190.9 \pm 28.9$ & $<20.0$ \\
\hline S3 & - & $\begin{array}{l}\text { Linum } \\
\text { usitatissimum }\end{array}$ & $27 / 07 / 09$ & $01 / 11$ & - & - & - & - & 1 & 1 & $<0.6$ & $<0.6$ & $8.4 \pm 2.7$ & $66.9 \pm 38.6$ & $<20.0$ \\
\hline S3 & - & L. usitatissimum & $27 / 07 / 09$ & $01 / 11$ & - & - & - & - & 1 & 2 & $0.6 \pm 0.3$ & $1.1 \pm 0.6$ & $15.4 \pm 6.6$ & $39.0 \pm 26.0$ & $<20.0$ \\
\hline S3 & - & L. usitatissimum & $31 / 08 / 09$ & $01 / 11$ & - & - & - & - & 1 & 1 & $<0.6$ & $3.3 \pm 1.3$ & $9.9 \pm 4.1$ & $156.2 \pm 79.1$ & $<20.0$ \\
\hline S3 & - & L. usitatissimum & $31 / 08 / 09$ & $01 / 11$ & - & - & - & - & 1 & 2 & $<0.6$ & $1.1 \pm 0.6$ & $18.3 \pm 2.1$ & $197.6 \pm 42.7$ & $<20.0$ \\
\hline S3 & - & L. usitatissimum & $21 / 09 / 09$ & $01 / 11$ & - & - & - & - & 1 & 1 & $<0.6$ & $<0.6$ & $9.0 \pm 1.9$ & $260.7 \pm 119.7$ & $<20.0$ \\
\hline S3 & - & L. usitatissimum & $21 / 09 / 09$ & $01 / 11$ & - & - & - & - & 1 & 2 & $<0.6$ & $<0.6$ & $14.5 \pm 5.6$ & $462.7 \pm 15.4$ & $<20.0$ \\
\hline S8 & - & L. usitatissimum & $28 / 07 / 09$ & $01 / 11$ & - & - & - & - & 3 & 1 & $<0.6$ & $0.6 \pm 0.3$ & $10.9 \pm 2.1$ & $794.2 \pm 56.3$ & $<20.0$ \\
\hline S8 & - & L. usitatissimum & $28 / 07 / 09$ & $01 / 11$ & - & - & - & - & 3 & 2 & $1.7 \pm 0.9$ & $2.8 \pm 1.3$ & $10.6 \pm 0.1$ & $211.1 \pm 32.7$ & $<20.0$ \\
\hline S8 & - & L. usitatissimum & $18 / 09 / 09$ & $01 / 11$ & - & - & - & - & 3 & 1 & $0.6 \pm 3.1$ & $1.1 \pm 0.6$ & $6.9 \pm 3.0$ & $2360.0 \pm 456.7$ & $<20.0$ \\
\hline S8 & - & L. usitatissimum & $18 / 09 / 09$ & $01 / 11$ & - & - & - & - & 3 & 2 & $8.9 \pm 1.9$ & $4.5 \pm 1.6$ & $11.5 \pm 2.7$ & $\begin{array}{c}9932.7 \pm \\
2491.6\end{array}$ & $<20.0$ \\
\hline S8 & - & L. usitatissimum & $28 / 09 / 09$ & $01 / 11$ & - & - & - & - & 3 & 1 & $1.1 \pm 0.6$ & $<0.6$ & $11.9 \pm 3.0$ & $800.1 \pm 89.4$ & $<20.0$ \\
\hline S8 & - & L. usitatissimum & $28 / 09 / 09$ & $01 / 11$ & - & - & - & - & 3 & 2 & $<0.6$ & $1.1 \pm 0.6$ & $8.3 \pm 0.3$ & $488.3 \pm 283.3$ & $<20.0$ \\
\hline
\end{tabular}

a Verticillium wilt severity and incidence of cauliflower was based on vascular discoloration of the stem. Specifically, the stems of 30 plants/field were cut lengthwise after harvest of the cauliflower heads, and scored for severity using a scale of 0 to 3 , in which $0=$ no discoloration, $1=<30 \%, 2=30$ to $70 \%$, and $3=>70 \%$ of the stem length $(=$ approximately $20 \mathrm{~cm}$ ) showing vascular discoloration. A disease index (severity) was calculated per field where: severity $=100 \times\left[\sum\left(i \times x_{i}\right)\right] /(3 \times$ number of plants) with $i=0$ to 3 severity rating and $x_{i}$ is the number of plants with score $i$.

$\mathrm{b}$ Verticillium wilt severity of flax was evaluated in each field based on visual evaluation of the stems with $1=$ no symptoms and $4=$ highly symptomatic.

$\mathrm{c}_{-}=$not determined.

$\mathrm{d}$ The wet sieving method as described by Harris et al. (17).

e The DFS + real-time PCR method was developed in this study and included density flotation of $100 \mathrm{~g}$ soil, filtration, DNA extraction, and real-time PCR analysis.

${ }^{\mathrm{f}}$ POVLT and PSKW = Belgian cauliflower fields, $\mathrm{Me}=$ Belgian experimental field, $\mathrm{S} 3$ and S8 = French flax fields.

g - = not applicable.

h Most recent crop.

i $\mathrm{d}=$ day, $\mathrm{m}=$ month, $\mathrm{y}=$ year.

j $1=0-30 \mathrm{~cm} ; 2=30-60 \mathrm{~cm}$ 
have been more widely used, it will become possible to state whether the assay is not confounding isolates of the unknown species with isolates of $V$. longisporum. Also, the $\beta$-tubulin sequence of the unknown species does not show a match with environmental samples currently present in GenBank. Thus, the limited importance of this unknown species is so far supported by the lack of DNA sequence records of this species.

Although morphological differentiation between $V$. dahliae/V. longisporum and $V$. tricorpus isolates is possible (but sometimes very difficult) using the wet sieving method (15), we also designed primers for specific detection of V. tricorpus. Similar to the primers of Moukhamedov et al. (28) for a conventional PCR assay, the realtime PCR primers developed in this study for $V$. tricorpus were designed based on the ITS region. Using the DFS + real-time PCR method, we demonstrated that $V$. tricorpus was present in all naturally infested fields tested. The role of $V$. tricorpus in these naturally infested soils needs to be further elucidated, and the real-time PCR assay developed in this study may help to evaluate the possible association of this species with disease-suppressive soils and/or the potential of isolates of this species to serve as biological control agents.

Regarding the sensitivity of the assay, we developed a method that was able to detect Verticillium in soils inoculated with as few as $0.1 \mathrm{~V}$. tricorpus and $0.5 \mathrm{~V}$. dahliae and $\mathrm{V}$. longisporum microsclerotia/g soil. This is more sensitive than the DNA macroarray method described by Lievens et al. (23), which had a detection limit of $6.7 \mathrm{~V}$. dahliae microsclerotia/g soil. The sensitivity of this new method is mainly attributed to the density flotation, as the amount of soil that was sampled was 8 times greater than with the wet sieving method (100.0 versus $12.5 \mathrm{~g}$ ) and at least 10 times greater than when DNA was extracted directly from soil (100.0 versus 0.25 to $10.0 \mathrm{~g}$ ). Moreover, the amount of soil equivalent that was analyzed was 2.8 times greater than with the wet sieving method (5.0 versus $1.8 \mathrm{~g}$ ) and at least 400 times greater than when DNA was directly extracted from soil (5.0 versus 0.00625 to $0.0125 \mathrm{~g}$ ). This was illustrated in the present study with the experiment in which $V$. dahliae $+V$. longisporum could be detected in five naturally infested soil samples when density flotation was used and only in two to three soil samples when DNA was extracted directly from $0.25 \mathrm{~g}$ and $10 \mathrm{~g}$ of soil, respectively. Due to the small amount of soil equivalent per PCR reaction in the samples from which the DNA was directly extracted, the calculation of the amount of Verticillium DNA per $g$ of soil uses a very large multiplication factor, resulting in overestimated amounts if there is detection. Thus, density flotation makes the new method more sensitive and more reproducible than when DNA is directly extracted from soil.

Table 5. Analysis of variance for effect of three soil prehandling treatments (drying, no drying, and storage at $4^{\circ} \mathrm{C}$ ) and two soils (POVLT and PSKW) on fg DNA/g soil for Verticillium tricorpus, V. longisporum, and V. dahliae $+V$. longisporum obtained with real-time polymerase chain reaction (PCR) using primer set pairs VtF4/VtR2, VlTubF2/VlTubR1, and VdTubF2/ VdTubR4, respectively

\begin{tabular}{|c|c|c|c|c|}
\hline Species & Source of variation & df & $\mathbf{M S}^{\mathbf{a}}$ & $P^{\mathbf{b}}$ \\
\hline V. tricorpus & $\begin{array}{l}\text { Soil } \\
\text { Prehandling } \\
\text { Soil } \times \text { prehandling } \\
\text { Error }\end{array}$ & $\begin{array}{c}1 \\
2 \\
2 \\
12\end{array}$ & $\begin{array}{c}711 \mathrm{E} 5 \\
139 \mathrm{E} 5 \\
145 \mathrm{E} 5 \\
73 \mathrm{E} 5\end{array}$ & $\begin{array}{l}0.009 * \\
0.192 \\
0.181\end{array}$ \\
\hline V. longisporum & $\begin{array}{l}\text { Soil } \\
\text { Prehandling } \\
\text { Soil } \times \text { prehandling } \\
\text { Error }\end{array}$ & $\begin{array}{c}1 \\
2 \\
2 \\
12\end{array}$ & $\begin{array}{c}166 \mathrm{E} 5 \\
235 \mathrm{E} 4 \\
335 \mathrm{E} 4 \\
82 \mathrm{E} 4\end{array}$ & $\begin{array}{l}0.001 \text { * } \\
0.097 \\
0.050\end{array}$ \\
\hline $\begin{array}{l}\text { V. dahliae }+ \\
\text { V. longisporum }\end{array}$ & $\begin{array}{l}\text { Soil } \\
\text { Prehandling } \\
\text { Soil } \times \text { prehandling } \\
\text { Error }\end{array}$ & $\begin{array}{c}1 \\
2 \\
2 \\
12\end{array}$ & $\begin{array}{c}311 \mathrm{E} 7 \\
986 \mathrm{E} 6 \\
957 \mathrm{E} 6 \\
38 \mathrm{E} 7\end{array}$ & $\begin{array}{l}0.015^{*} \\
0.117 \\
0.127\end{array}$ \\
\hline
\end{tabular}

${ }^{\mathrm{a}} \mathrm{MS}=$ mean of squares

${ }^{\text {b }} P=$ Probabilities associated with corresponding $F$ tests. Values marked with $*$ indicate a significant difference $(P<0.05)$.
Sensitivity of the assay also is determined by the real-time PCR target region and primers. The detection of $V$. tricorpus was at least 10 times more sensitive than that of $V$. longisporum and $V$. dahliae. This difference was due to the multi-copy versus single-copy nature of the respective targets: $V$. tricorpus primers were designed based on the multi-copy rDNA ITS region, whereas the $V$. longisporum and $V$. dahliae primers were designed based on the singlecopy $\beta$-tubulin gene for specificity reasons. A few studies have shown that the number of rDNA copies can fluctuate with the age and stage of growth of the fungus, and nonorthologous copies of the ITS region among strains of the same species have been described (1). Given that such inconsistencies may affect the quantification of pathogen propagule numbers and potential comparisons among samples, we have determined the copy number of five $V$. tricorpus isolates from different origins as described by Debode et al. (11) for $C$. acutatum and showed that the difference in copy number between the five tested isolates was small (mean copy number $\pm \mathrm{SE}=18.60 \pm 1.28$ ). Based on these results, the ITS primers were preferred when analyzing soil samples.

The correlation between the results of the wet sieving and the DFS + real-time PCR methods for 25 naturally infested soils was very high for $V$. tricorpus, but there was no correlation for $V$. dahliae $+V$. longisporum. The reason for this species-related difference is that for $V$. dahliae $+V$. longisporum there was a very low recovery using the wet sieving method, which was not observed for $V$. tricorpus. Our results indicate that the viability or germinability of $V$. dahliae microsclerotia may be reduced during extended dry storage, while the viability and germinability of the $V$. tricorpus microsclerotia may be less affected by dry storage. More specifically, the Me and flax soil samples had been stored dry for 6 months and 1.5 years, respectively. Presumably the viability or germinability of the $V$. dahliae microsclerotia decreased over these time periods, while their DNA stayed intact due to the limited microbial activity in these dried samples. Therefore, this DNA was measured with the molecular method and represents the more appropriate inoculum level at the time of sampling. In contrast, the recovery of $V$. tricorpus in these soils was higher and correlated with the amount of $V$. tricorpus DNA detected. Further research is necessary to determine the effect of dry storage on the germinability and viability of microsclerotia of different Verticillium species. The inter-species difference should be less for fresh samples or samples stored under normal moisture conditions, and this was observed with the inoculated soil samples.

As real-time PCR also detects DNA from dead or dormant cells in dry-stored soils, the question arises as to the possibility of an overestimation of the inoculum using this real-time PCR method. Although it is generally assumed that DNA from dead cells usually degrades fairly rapidly in natural moist soil due to microbial activity (23), experimental data concerning DNA degradation speed in dead microsclerotia in soil would be welcome to further rule out the possibility of bias due to detection of dead microsclerotia.

Using the wet sieving method, seasonal fluctuations in the concentration of recoverable $V$. longisporum microsclerotia has been detected in the field, even in uncultivated soils (S. C. França, M. Höfte, and K. Spiessens, unpublished data). It is unclear whether these seasonal fluctuations are attributed to dormancy of microsclerotia or the weakness of microsclerotia in the soil after a period of sporulation $(26,33)$. The real-time PCR (DNA-based) method incorporates this dormant/weak inoculum into the soil assay. Analysis of soil samples from cultivated as well as uncultivated soils using both the wet sieving and real-time PCR method at multiple time points throughout the year may help to clarify this issue.

Another factor to consider when using real-time PCR is that DNA is extracted from a soil environment. One of the problems encountered when amplifying templates collected from soil for PCR-based quantification of a pathogen is the presence of other compounds extracted along with the DNA that can influence amplification efficiency. Analysis of 25 naturally infested soil samples showed that the CV of the real-time PCR results was 0.34 . This is 
quite low given the transformation from a log scale and well within the amount of variability observed with the conventional plating methods (36). Therefore, the results can be considered reproducible. In addition, the DNA extracted from the Me soil contained low amounts of PCR inhibitors, as $\Delta \mathrm{Ct}_{\text {dilution }}$ was not significantly different from the slope of the standard curve. Although $\Delta \mathrm{Ct}_{\text {spiked }}$ was significantly different from 0 , it was very low $(0.2)$ and ranged within the variability of the real-time PCR system (1). The strongly reduced amount of PCR inhibitors in the DNA of these soil samples can be attributed to the sucrose density gradient approach used in this study and the MoBio Power Soil DNA extraction system, which is especially designed to extract DNA from environmental samples containing a high humic acid content. However, for soils that are very rich in organic matter, the $100 \mathrm{~g}$ sample can be split in half, with only a limited reduction in detection limit.

This study showed that the time needed for analysis of a soil sample for Verticillium species can be reduced from at least 25 days with the wet sieving method to only 1 day with the DFS + real-time PCR method. Using the wet sieving method, air-drying of the soil is necessary to eliminate nondesired propagules, such as conidia and mycelial fragments sensitive to desiccation (4), and thus increase specificity of the assay. Density flotation eliminates the need to dry the soil samples for 2 weeks before real-time PCR analysis, making it possible to perform the whole assay (sucrose flotation, filtering, DNA extraction, and real-time PCR assay) in 1 day. If it is not possible to perform the analysis directly after soil sampling, the wet soil can be stored at $4^{\circ} \mathrm{C}$ for at least 14 days before analysis.

Finally, in the present study, data were included on disease incidence and severity with the cauliflower and the flax soils. For the cauliflower soils, it was demonstrated that the extent of the symptoms was correlated with the identity of the specific Verticillium species present, and not with the total amount of microsclerotia detected. For the flax soils, it was demonstrated that the highest amount of $V$. dahliae DNA was found in the flax field with Verticillium symptoms (S8), and that this difference was statistically significant. These results indicate that the new method developed in this study can help in evaluating the risk of soils for host-specific development of Verticillium wilt and contribute to sustainable disease control strategies.

\section{Acknowledgments}

We thank A. von Tiedemann, C. Dixelius, J. C. Goud, and A. Infantino for providing Verticillium isolates; K. Spiessens (PSKW), S. Pollet (POVLT), and E. Cariou - Pham (ITL) for providing naturally infested soil samples; L. Tyvaert and S. Inghelbrecht for technical assistance; and M. Levenson for English language editing of this manuscript.

\section{Literature Cited}

1. Atallah, Z. K., Bae, J., Jansky, S. H., Rouse, D. I., and Stevenson, W. R. 2007. Multiplex real-time quantitative PCR to detect and quantify Verticillium dahliae colonization in potato lines that differ in response to Verticillium wilt. Phytopathology 97:865-872.

2. Barbara, D. J., and Clewes, E. 2003. Plant pathogenic Verticillium species: How many of them are there? Mol. Plant Pathol. 4:297-305.

3. Berbegal, M., Ortega, A., García-Jiménez, J., and Armengol, J. 2007. Inoculum density-disease development relationship in Verticillium Wilt of artichoke caused by Verticillium dahliae. Plant Dis. 91:1131-1136.

4. Butterfield, E. J., and Devay, J. E. 1977. Reassessment of soil assays for Verticillium dahliae. Phytopathology 67:1073-1078.

5. Clewes, E., Edwards, S. G., and Barbara, D. J. 2008. Direct molecular evidence supports long-spored microsclerotial isolates of Verticillium from crucifers being interspecific hybrids. Plant Pathol. 57:1047-1057.

6. Collado-Romero, M., Jimenez-Diaz, R. M., and Mercado-Blanco, J. 2010. DNA sequence analysis of conserved genes reveals hybridization events that increase genetic diversity in Verticillium dahliae. Fungal Biol. 114:209-218.

7. Collins, A., Okoli, C. A. N., Morton, A., Parry, D., Edwards, S. G., and Barbara, D. J. 2003. Isolates of Verticillium dahliae pathogenic to crucifers are of at least three distinct molecular types. Phytopathology 93:364-376.

8. Davis, J. R., Everson, D. O., Sorensen, L. H., and Schneider, A. T. 2000. Associations of Verticillium tricorpus with soil suppressiveness of Verticillium wilt of potato. Pages 347-351 in: Advances in Verticillium: Research and Disease Management. E. C. Tjamos, R.C. Rowe, J. B. Heale, and D. R. Fravel, eds. American Phytopathological Society, St Paul, MN.
9. Debode, J. 2005. Integrated control of Verticillium wilt of cauliflower. Ph.D. thesis. Ghent University, Ghent, Belgium.

10. Debode, J., Clewes, E., De Backer, G., and Hofte, M. 2005. Lignin is involved in the reduction of Verticillium dahliae var. longisporum inoculum in soil by crop residue incorporation. Soil. Biol. Biochem. 37:301-309.

11. Debode, J., Van Hemelrijck, W., Baeyen, S., Creemers, P., Heungens, K., and Maes, M. 2009. Quantitative detection and monitoring of Colletotrichum acutatum in strawberry leaves using real-time PCR. Plant Pathol. 58:504-514.

12. Eynck, C., Koopmann, B., Grunewaldt-Stoecker, G., Karlovsky, P., and von Tiedemann, A. 2007. Differential interactions of Verticillium longisporum and $V$. dahliae with Brassica napus detected with molecular and histological techniques. Eur. J. Plant Pathol. 118:259-274.

13. Ginzinger, D. G. 2002. Gene amplification using real-time quantitative PCR: An emerging technology hits the mainstream. Exp. Hematol. 30:503512.

14. Goud, J. C., and Termorshuizen, A. J. 2003. Quality of methods to quantify microsclerotia of Verticillium dahliae in soil. Eur. J. Plant Pathol. 109:523534.

15. Goud, J. K. C., Termorshuizen, A. J., and Gams, W. 2003. Morphology of Verticillium dahliae and V. tricorpus on semi-selective media used for the detection of $V$. dahliae in soil. Mycol Res. 107:822-830.

16. Harris, D. C., and Yang, J. R. 1996. The relationship between the amount of Verticillium dahliae in soil and the incidence of strawberry wilt as a basis for disease risk prediction. Plant Pathol. 45:106-114.

17. Harris, D. C., Yang, J. R., and Ridout, M. S. 1993. The detection and estimation of Verticillium dahliae in naturally infested soil. Plant Pathol. 42:238-2350.

18. Huisman, O. C., and Ashworth, L. J. 1974. Verticillium albo-atrum: Quantitative isolation of microsclerotia from field soils. Phytopathology 64:1159-1163.

19. Inderbitzin, P., Davis, R. M., Bostock, R. M., and Subbarao, K. V. 2011. The ascomycete Verticillium longisporum is a hybrid and a plant pathogen with an expanded host range. PLoS ONE 6:e18260.

20. Ispahani, S. K., Goud, J. C., Termorshuizen, A. J., Morton, A., and Barbara, D. J. 2008. Host specificity, but not high-temperature tolerance, is associated with recent outbreaks of Verticillium dahliae in chrysanthemum in the Netherlands. Eur. J. Plant Pathol. 122:437-442.

21. Karapapa, V. K., Bainbridge, B. W., and Heale, J. B. 1997. Morphological and molecular characterization of Verticillium longisporum comb. nov., pathogenic to oilseed rape. Mycol. Res. 101:1281-1294.

22. Klosterman, S. J., Atallah, Z. K., Vallad, G. E., and Subbarao, K. V. 2009. Diversity, pathogenicity, and management of Verticillium species. Annu. Rev. Phytopathol. 47:39-62.

23. Lievens, B., Brouwer, M., Vanachter, A. C. R. C., Levesque, C. A., Cammue, B. P. A., and Thomma, B. P. H. J. 2005. Quantitative assessment of phytopathogenic fungi in various substrates using a DNA macroarray. Environ. Microbiol. 7:1698-1710.

24. Mahuku, G. S., and Platt, H. W. 2002. Quantifying Verticillium dahliae in soils collected from potato fields using a competitive PCR assay. Am. J. Potato Res. 79:107-117.

25. Mauchline, T. H., Kerry, B. R., and Hirsch, P. R. 2002. Quantification in soil and the rhizosphere of the nematophagous fungus Verticillium chlamydosporium by competitive PCR and comparison with selective plating. Appl. Environ. Microbiol. 68:1846-1853.

26. Menzies, J. D., and Griebel, G. E. 1967. Survival and saprophytic growth of Verticillium dahliae in uncropped soil. Phytopathology 57:703-709.

27. Mol, L., Scholte, K., and Vos, J. 1995. Effects of crop rotation and removal of crop debris on the soil population of two isolates of Verticillium dahliae. Plant Pathol. 44:1070-1074.

28. Moukhamedov, R., Hu, X., Nazar, R. N., and Robb, J. 1994. Use of polymerase chain reaction-amplified ribosomal intergenic sequences for the diagnosis of Verticillium tricorpus. Phytopathology 84:256-259.

29. O'Donnell, K., and Cigelnik, E. 1997. Two divergent intragenomic rDNA ITS2 types within a monophyletic lineage of the fungus Fusarium are nonorthologous. Mol. Phylogenet. Evol. 7:103-116.

30. Qin, Q. M., Vallad, G. E., and Subbarao, K. V. 2008. Characterization of Verticillium dahliae and V. tricorpus isolates from lettuce and artichoke. Plant Dis. 92:69-77.

31. Qin, Q. M., Vallad, G. E., Wu, B. M., and Subbarao, K. V. 2006 Phylogenetic analyses of phytopathogenic isolates of Verticillium spp. Phytopathology 96:582-592.

32. Robinson, N., Platt, H. W., and Hale, L. R. 2007. Verticillium dahliae interactions with $V$. albo-atrum 'Group 2' and V. tricorpus and their effects on Verticillium wilt disease development in potato. Am. J. Potato Res. $84: 229-235$.

33. Schnathorst, W. C. 1965 . Origin of new growth in dormant microsclerotial masses of Verticillium albo-atrum. Mycologia 57:343-351.

34. Schnathorst, W. C. 1981. Life cycle and epidemiology of Verticillium. Pages 81-111 in: Fungal Wilt Diseases of Plants. M. E. Mace, A. A. Bell, and C. H. Beckman, eds. Academic Press, New York.

35. Steventon, L. A., Fahleson, J., Hu, Q., and Dixelius, C. 2002. Identification of the causal agent of Verticillium wilt of winter oilseed rape in Sweden, 
V. longisporum. Mycol. Res. 106:570-578.

36. Termorshuizen, A. J., Davis, J. R., Gort, G., Harris, D. C., Huisman, O. C., Lazarovits, G., Locke, T., Vara, J. M. M., Mol, L., Paplomatas, E. J., Platt, H. W., Powelson, M., Rouse, D. I., Rowe, R. C., and Tsror, L. 1998. Interlaboratory comparison of methods to quantify microsclerotia of Verticillium dahliae in soil. Appl. Environ. Microbiol. 64:3846-3853.

37. Van Hemelrijck, W., Debode, J., Heungens, K., Maes, M., and Creemers, P. 2010. Phenotypic and genetic characterization of Colletotrichum isolates from Belgian strawberry fields. Plant Pathol. 59:853-861.

38. White, T. J., Bruns, T., Lee, S., and Taylor, J. W. 1990. Amplification and direct sequencing of fungal ribosomal RNA genes for phylogenetics. Pages 315-322 in: PCR Protocols: A Guide to Methods and Applications. M. A.G. D. S. J. W. Innis, ed. Academic Press, New York.

39. Xiao, C. L., and Subbarao, K. V. 1998. Relationships between Verticillium dahliae inoculum density and wilt incidence, severity, and growth of cauliflower. Phytopathology 88:1108-1115. 